\title{
Enhancing Students' Creative Thinking Skills through the Process of Teaching Business Research
}

\author{
Nitaya Wongpinunwatana \\ Thammasat University
}

The objective of this study is to propose a model for enhancing students' creative thinking skills. This study collects data from 104 graduate students studying business research. A questionnaire relating to local thinking and collaboration was developed. Analytical thinking and creative thinking measurements were collected from graduate school entrance exam scores and instructors' review of student's research reports. The findings suggest that students' logical thinking and collaboration directly affect analytical thinking and indirectly affect creative thinking via analytical thinking. In addition, students' analytical thinking directly affects creative thinking. Participants in this research were students in one public university, so they may not be representative of students at other universities. Therefore, the effects of logical thinking, collaboration, and analytical thinking on creative thinking need to be investigated further. This research is one of only a few papers proposing a model for enhancing creative thinking. The model posits that logical thinking, analytical thinking and collaboration enhance creative thinking.

\section{INTRODUCTION}

Digital technology, such as social media, mobile telephones, data analytics, cloud computing, and internet of things, affects students' skills, especially the skills of business students. Wagner (2018) summarized seven survival skills defined by business leaders: critical thinking and problem solving, collaboration across networks and leading by influence, agility and adaptability, initiative and entrepreneurship, effective oral and written communication, accessing and analyzing information, and curiosity and imagination. These skills are especially needed with the accelerating changes in technology and the ensuing disruptions. Students, however, do not possess many of these skills, especially thinking skills, to operate in a disruptive environment. To solve this issue, many academic and government institutions have indicated the need for research with the aim of enhancing students' creative thinking skills (Mayer, 1989; Palaniappan, 2014).

Recently, most educational institutions employed both technology and active learning strategies to enhance students' thinking skills (Tan, 2006). Improving students' thinking skills is significantly important for people in a rapidly changing and emerging technologically-oriented world (Cotton, 1991). In addition, critical and creative thinking skills are important and essential components of innovation for business students (Nimalathasan \& Valerin, 2010; Pinard \& Allio, 2005; Kealey et al., 2005). Developing students' creative thinking skills are among the highest priorities of all universities.

Thinking and learning skills are related in part to teaching processes that apply in a variety of real-life contexts. Thinking skills are both individual and social. This skill is related to collaborative learning. The 
learning skill refers to the way that individuals are able to understand specific cognitive functions - e.g., systematic thinking, inferential thinking, and analogical thinking (Feuerstein, 1990). Creative thinking skills to enable students to generate and extend ideas, to apply imagination, and to look for creative thinking outcomes are the most important skills (Wegerif, 2002). This research proposes a model affecting students' creative thinking skills.

\section{THEORETICAL BACKGROUND}

Based on the literature review, significant factors affecting creative thinking skills are logical thinking, analytical thinking, and collaboration. The explanation of these factors is as follows.

\section{Logical Thinking}

Logical thinking is a process that involves moving from antecedents to related consequents (McMillan, 2016). Consequents are the logical results that follow from antecedent statements. Most people place a high value on a person who displays strong logical thinking or reasoning skills. These skills are the ability to organize observed data by using classification, seriation, correspondence, and other operations (Linn \& Thier, 1975). The evidence indicates that skills in developing logical thinking abilities are being taught to students. In addition, Morgan and Thiagrajan (2009) showed that ethics, common sense and logic are partly interconnected. In other words, if persons are able to set ethical principles, they will have common sense and be able to think logically.

Previous research addressed whether logical thinking is the only way to face and solve problems. Logical thinking leads to sequences of ideas (Saaty 1994). Additionally, Renner and Philips (1980) noticed that students possessing logical thinking should improve their thinking abilities. Moreover, Berg and Phillips (1994) investigated the relationship between students' logical thinking structures and their ability to build and interpret line graphs. This result showed that students who had low levels of logical thinking are not able to build and interpret graphs. Prior studies found that most students who had not been taught physics but had several mathematics courses are able to interpret the graph by using verbal analytical strategies (Hegarty \& Kozhenikov, 1999).

\section{Analytical Thinking}

Analytical thinking is the powerful thinking tool that aids in situational understanding. Analytical thinking also is defined as the ability to scrutinize and divide facts and thoughts into strengths and weaknesses (Freed \& Pena, 2000). Bruning (2005) stated that students would gain creative thinking by stimulating them to apply their analytical thinking skills and then use their knowledge to solve a problem. Nowadays, it is really necessary to have analytical thinking in order to exploit knowledge (Garcia, 2012). Analytical skills are best proven in student essays where these skills are used synergistically (Pally, 2001). Moreover, higher institutions are committed to teaching critical thinking and evaluative skills that students need for achievement in the workplace (Paul, 1989). Critical thinking means thinking analytically to determine the authenticity, accuracy, or value of something by seeking reasons and alternatives for the situation based on evidence (Cotton, 1991). Nimalathasan and Valeriu (2010) stated that critical thinking is an essential part of creativity.

\section{Collaboration Learning}

Collaboration learning is the joint effort of all participants in a group of students working together to search for understanding, meaning, or a solution to accomplish a task (Hong, 2011). Collaboration learning requires individuals to take responsibility for a specific section and then coordinate their respective parts together (Kyndt et al., 2013). Knowledge can be created within members in a group where members actively interact by sharing experiences and take on asymmetric roles (Mitnik, 2009; Trach, 2012).

Collaboration can be in the form of group-based collaboration or idea-centered collaboration (Hong, 2011). Group-based collaboration is a method where each student within a group is assigned a well- 
defined role to complete a whole task; each student does his/her subtask and then merges the subtasks together like a jigsaw puzzle. Idea-centered collaboration is a method where students work together without forming group roles or reference to a general plan. Collaborative learning is very important in achieving critical thinking (Gokhale, 1995). Individuals are able to learn effectively and efficiently and retain more information when they work in a group rather than individually (Gokhale, 1995; Hong, 2011).

\section{Creative Thinking}

Creative thinking is the process of coming up with new ideas or new approaches to issues. By developing this skill, individuals differentiate themselves from others. The thinking skill will always be in high demand, especially in this high-technology era, and is key for students' success in their future careers. Over the last few years, information technology has undergone major changes such as big data, block chains, cloud storage, etc. Students who possess creative thinking will demonstrate their capabilities in the form of inferences and interpretation, assumptions, determinations of concept, theories, principles and definitions, and determinations of frame of reference (Pual \& Elder, 2012). Creative thinking skill is something that can be learned. Creative thinking is a four-stage process: clarifying, ideating or brainstorming, developing, and finally implementing.

Creative thinking and critical thinking are often inseparable. Critical thinking is the ability to think clearly and rationally about what to do or what to believe. It is an essential part of creativity because people need critical thinking to evaluate and improve their creative ideas (Lau \& Chan, 2004; Nimalathasan \& Valeriu, 2010). The new ideas being generated from creative thinking must be useful and relevant to the problem to be solved. Critical thinking plays a crucial role in evaluating new ideas, selecting the best ones, and modifying those ideas if necessary (Lau \& Chan, 2004; Paul \& Elder, 2012).

\section{RESEARCH MODEL AND HYPOTHESES}

Based on the above literature review, a model of enhancing creative thinking is proposed (see Figure 1). This model provides instructors and policy makers with insights into how the teaching process will be facilitated in institutions to enhance students' creative thinking. Significant factors affecting creative thinking are taken into account. These factors include logical thinking, analytical thinking, and collaboration. The model indicates that the effects of logical thinking directly impacts creative thinking via analytical thinking. In addition, analytical thinking is a mediator between collaboration and creative thinking. The hypotheses developed from this model are discussed as follows.

FIGURE 1

MODEL OF ENHANCING CREATIVE THINKING

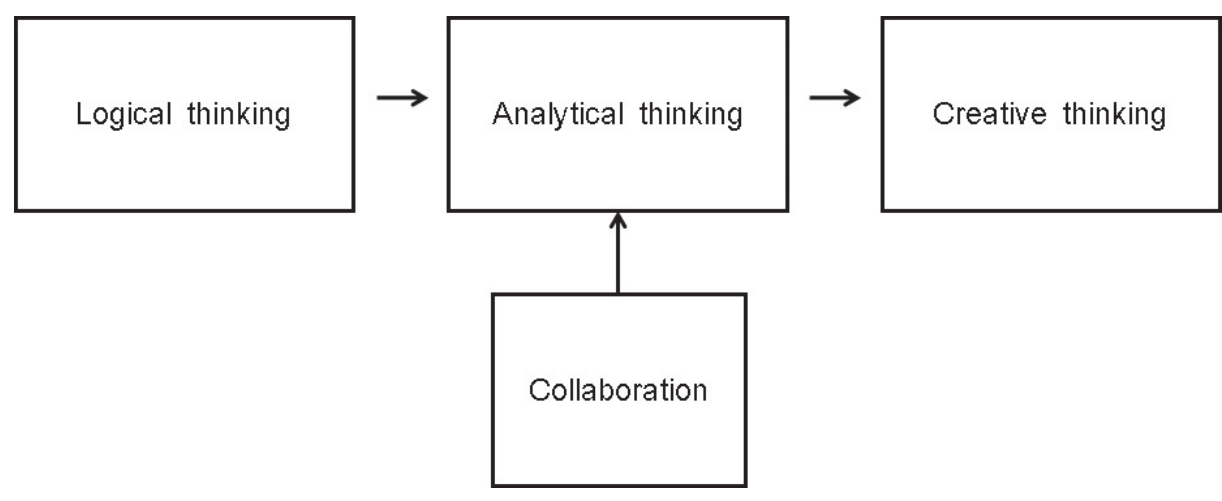

A person's logical thinking comes from the experience accumulated by the society the person lives in, and the norms and rules that are part of that society, such as law. Oftentimes, people solve problems in their everyday life by breaking the problems down into smaller pieces. These smaller pieces can be 
analyzed using the norms and rules that are integral to their society. They then find the opportunities and/or lessons from analyzing these small problems. Therefore, the logical thinking enables the analytical which in turn leads to progress in knowledge (Bruning, 1980). Hence, this study proposes that:

\section{H1: Logical thinking by students positively influences their analytical thinking.}

Many researchers (e.g., Girot, 2000; Daly, 2001; Profetto-McGrath, 2003) discuss the importance of developing strategies to teach and assess critical thinking in students. Educators view graduate study as primarily contributing to practical competency-based tasks with critical/creative thinking (Banning, 2006). The key characteristics of critical/creative thinking are the analytical consideration of reasons or evidence and the inclination to predict consequences by using verifiable information (Simpson \& Courtneay, 2002; Profetto-McGrath, 2003). Thus, this study hypothesizes that:

\section{H2: Analytical thinking positively influences student's creative thinking.}

Learning is collaborative, communicative, and cooperative. When working in groups with a high level of interaction, students develop analytical thinking (Tan, 2006: King, 2007). They can reach a new level of understanding during interactions where more complex cognitive activities occur, such as analytical thinking, integration of ideas, and reasoning (Rose et al., 2008). The activities among members within a group influence the analytical thinking (Tan, 2006; King, 2007). Hence, this study proposes that:

\section{H3: Collaborative learning positively influences student's analytical thinking.}

\section{METHOD}

The sample for this study consisted of 104 graduate students enrolled in business research classes at a business school in a public university in Thailand. This group included 71 students studying for their Master of Business Administration (MBA) degree, and 33 students studying for their Master of Science in Management Information Systems (MSMIS) degree. Business research is a compulsory subject required to receive both of these master's degrees.

The research was conducted in lecture rooms of the university. Students were divided into groups to do a research project, and each group selected their research topic. This research course was divided into fifteen class periods with three hours in each period. Six periods were used to teach research concepts and processes emphasizing quantitative research. Two periods were used to teach qualitative research while five periods were used for statistical concepts. The last two periods were used for research presentations by each group. These periods allowed students in each group to present their conceptual models to the other groups in order to be evaluated for originality and uniqueness (Palaniappan, 2014).

At the end of this research course, all students had to answer a questionnaire measuring their logical thinking and collaboration. Logical thinking questions were based on logical thinking measurements of Phillip (2009) and Aizawa (2001). For collaboration, this study applied questions from Wolff (2010) to measure collaboration of the members in each research group. The collaboration questions were used to measure activity, outcome, and relationships. Mean scores for local thinking and collaboration were calculated based on students' responses. The analytical thinking factor was collected from the students'

SMART-II score (Scholarly Management Aptitude Requirement Test). SMART-II is modeled on the GRE and GMAT, and all applicants to this business school are required to take this entrance exam and have at least a minimum score set by the business school. This test measures student performance in two sections (quantitative ability and analytical ability); this research used students' scores in the analytical part to measure analytical thinking.

This research measured students' creative thinking from their research reports, which were scored using four components of creative thinking: originality, fluency, flexibility, and elaboration, as based on previous research (e.g., Guiford, 1959; Palaniappan, 2014). Originality is the ability to generate new ideas 
for given problems. Fluency is the ability to produce a variety of possible solutions to problems. Flexibility is the ability to mix various theories in order to form new ideas. Elaboration is the ability to express an illustration of the argument. The overall score of each students' research report was determined by two instructors who each have more than ten years of experience teaching business research. In addition, Cohen's Kappa coefficient was used to calculate the consistency of the two instructors' evaluations. Cohen's Kappa is 0.75, which is higher than 0.65 (Cohen, 1960), thereby indicating the same direction of assessments.

\section{RESULTS}

The data was analyzed using a software package based on structural equation modeling (SEM) techniques. The SEM approach is used to evaluate causal relationships among constructs in a proposed model simultaneously. The commonly used applications for SEM are confirmatory factor analysis (testing of the measurement model) and path analysis (testing of the causal model). This research tested the causal model instead of the measurement model because data for logical thinking and analytical thinking had only one construct. The mean score for collaboration and creative thinking measurement also was calculated and used for statistical analysis.

This research considered the model to be fit if the chi-square is low relative to the degrees of freedom with an insignificant $p$ value $(\mathrm{p}>0.05)$. The relative chi-square should be 3 or less (Kline, 2011; Tabachnik \& Fidell, 2013). The value of RMSEA should be less than 0.07 (Steiger, 2007), and goodnessof-fit index (GFI) and comparative fit index (CFI) should be greater than 0.90 (Segars \& Grover, 1993). The value of RMS should have a small value (Tabachnik \& Fidell, 2013), and AGFI should be larger than 0.8 (Bagozzi \& Yi, 1988; Hair et al., 1998; JÖreskog \& SÖrbom, 1994). The resulting causal models have good fits (chi-square $=2.366, \mathrm{df}=2, \mathrm{p}$-value $=0.306$, chi-square $/ \mathrm{df}=0.592, \mathrm{GFI}=0.983, \mathrm{AGFI}=0.915$, $\mathrm{CFI}=0.998, \mathrm{RMSEA}=0.053, \mathrm{RMR}=0.102$ ). Each indicator is significant at 0.05 levels. Individual item $\mathrm{R}^{2}$ is 0.678 and 0.705 .

The results of direct, indirect, and total effect in the standardized score of the adjusted model, and goodness-of-fit indices of the proposed model are exhibited in Table 1. The results provide good support for the three hypotheses. All three path coefficients are statistically significant $(\mathrm{p}<0.05)$. Logical thinking and collaboration have a positive impact on analytical thinking $\left(\mathrm{R}^{2}=0.678\right)$, so $\mathrm{H} 1$ and $\mathrm{H} 2$ are supported. The relationship between analytical thinking and creative thinking is statistically significant, so H3 is supported. Finally, logical thinking and collaboration have an indirect effect on creative thinking. The overall impact of logical thinking, collaboration, and analytical thinking on creative thinking is high $\left(\mathrm{R}^{2}=0.705\right)$. 
TABLE 1

DIRECT, INDIRECT, AND TOTAL EFFECT IN STANDARDIZED

SCORE OF ADJUSTED MODEL

\begin{tabular}{|c|c|c|c|c|c|}
\hline \multirow[t]{2}{*}{ Dependent variables } & \multirow[t]{2}{*}{$\mathbf{R}^{2}$} & \multirow[t]{2}{*}{ Relation } & \multicolumn{3}{|c|}{ Independent variables } \\
\hline & & & $\begin{array}{c}\text { Logical } \\
\text { thinking }\end{array}$ & $\begin{array}{c}\text { Analytical } \\
\text { thinking }\end{array}$ & Collaboration \\
\hline \multirow{3}{*}{ Analytical thinking } & \multirow{3}{*}{0.678} & Direct effect & $0.416^{*}$ & - & $0.565^{*}$ \\
\hline & & Indirect effect & - & - & - \\
\hline & & Total effect & $0.416^{*}$ & - & $0.565^{*}$ \\
\hline \multirow{3}{*}{ Creative thinking } & \multirow{3}{*}{0.705} & Direct effect & - & $0.732 *$ & - \\
\hline & & Indirect effect & $0.305^{*}$ & - & $0.414 *$ \\
\hline & & Total effect & $0.305^{*}$ & $0.732 *$ & $0.414 *$ \\
\hline
\end{tabular}

$* \mathrm{p}<0.05$

\section{CONCLUSION}

This study examines the direct and indirect effects of logical thinking, analytical thinking, and collaboration relationships on creative thinking. Structural equation modeling (SEM) analyses confirm that students' logical thinking and students' collaboration directly affect students' analytical thinking and indirectly affect students' creative thinking via students' analytical thinking. In addition, students' analytical thinking directly affects students' creative thinking. In summary, the results of this study suggest that instructors should provide logical thinking coursework to students. In addition, instructors should arrange and encourage collaboration among members of students within groups, which may affect knowledge building (Hong, 2011). These arrangements will affect students' analytical thinking, which in turn, affects students' creative thinking.

This research has several limitations that hamper the ability to generalize the study results. Participants were students in one public university in Thailand. These students may not represent all students in all universities. Therefore, the results should be used cautiously.

The effects of logical thinking, collaboration, and analytical thinking on creative thinking need to be investigated further. As business research is a compulsory course required to earn a master's degree, students may put more effort in analyzing and synthesizing the assigned research project more so than they would if the course was not compulsory. Future research should be designed to consider extending study to other participants, without the compulsory course, to generalize the research results. Finally, the attributes of instructors and students may affect methods to increase students' creative thinking (Palaniappan, 2014). This research emphasizes only attributes of students. Therefore, future research should investigate attributes of both instructors and students in more detail. 


\section{REFERENCES}

Aizawa, A. (2001). Atama Ga Yokunaru Ronri Puzzle. Japan: Yukie ABE.

Bagozzi, R. P., \& Yi, Y. (1988). On the evaluation of structural equation models. Journal of the Academy of Marketing Science, 16(1), 74-94.

Banning, M. (2006). Nursing research: perspectives on critical thinking. British Journal of Nursing, $15(8), 458-461$.

Berg, C. A., \& Phillips, D. G. (1994). An investigation of the relationship between logical thinking structures and the ability to construct and interpret line graphs. Journal of Research in Science Teaching, 31, 323-344.

Bruning, K. (2005). The role of critical thinking in the online learning environment. International Journal of Instructional Technology and Distance Learning, 2, 21-31.

Cohen, J. (1960). A coefficient of agreement for nominal scales. Educational and Psychological Measurement, 20, 37-46.

Cotton, K. (1991). Teaching Thinking Skills: School Improvement Research Series. Retrieved June 15, 2006, from https://educationnorthwest.org/sites/default/files/TeachingThinking Skills.pdf.

Daly, W. M. (2008). The development of an alternative method in the assessment of critical thinking as an outcome of nursing education. Journal of Advanced Nursing, 36(1), 120-30.

Feuerstein, R. (1990). The theory of structural modifiability. In B. Presseisen (Ed.), Learning and thinking styles: Classroom interaction. Washington, DC: National Education Association.

Freed, C., \& Pena, R. (2000). Minority Education and Analytical Thinking Skills: Traditionalizing Disempowerment. The High School Journal, 85(2), 24-32.

Garcia, L. M. (2012). Understanding design thinking, exploration and exploitation: Implications for design strategy. IDBM (International Design Business Management), 2, 150-161.

Girot, E. A. (2000). Graduate nurses: critical thinkers or better decision makers? Journal of Advanced Nursing, 31(2), 288-297.

Gokhale, A. (1995). Collaborative learning enhances critical thinking. Journal of Technology Education, $7(1), 22-30$.

Hair, J. F., Anderson, R.E., Tatham, R.L., \& Black, W.C. (1998). Multivariate Data Analysis, 5th ed. Englewood Cliffs, NJ: Prentice-Hall.

Hegarty, M. \& Kozhenikov, M. (1999). Types of Visual-Spatial Representation and Mathematical Problem Solving. Journal of Educational Psychology, 91(4), 684-689.

Hong, H. (2011). Beyond Group Collaboration: Facilitating an Idea-centered View of Collaboration through Knowledge Building in a Science Class of Fifth-graders. The Asia Pacific Education Researcher, 20(2), 246-260.

JÖreskog, K., \& SÖrbom, D. (1994). Structural Equation Modeling with the SIMPLIS Command Language. Chicago, IL: Scientific Software International.

Kealey, B. T., Holland, J., \& Watson, M. (2005). Preliminary Evidence on the Association between Critical Thinking and Performance in Principles of Accounting. Issues in Accounting Education, 20(1), 33-49.

King, A. (2007). Scripting Collaborative Learning Processes: A Cognitive Perspective. Computer Supported Collaborative Learning, 6, 13-37.

Kline, R. B. (1998). Principles and practice of structural equation modeling. New York: Guilford Press.

Kyndt, E., Raes, E., Lismont, B., Timmers, F., Cascallar, E., \& Dochy, F. (2013). A meta-analysis of the effects of face-to-face cooperative learning. Do recent studies falsify or verify earlier findings?. Educational Research Review, 10, 133-149.

Lau, J., \& Chan, J. (2004). What is critical thinking? Retrieved May 25, 2016, from http://philosophy.hku.hk/think/citical/ct.php.

Linn, M. C., \& Their, H. D. (1975). The effect of experiential science on development logical thinking in children. Journal Research in Science Teaching, 12(1), 49-62. 
McMillan, D. (2016). Antecedents lead to consequents. Retrieved November 15, 2016, from www.study.com/academy/lesson/logical-thinking-definition-process-quiz.html.

Mayer, R. E. (1989). Cognitive views of creativity: Creative teaching for creative learning. Contemporary Educational Psychology, 14(3), 203-211.

Mitnik, R, Recabarren, M., Nussbaum, M., \& Soto, A. (2009). Collaborative Robotic Instruction: A Graph Teaching Experience. Computers \& Education, 53(2), 330-342.

Morgan, C. R. \& Thiagarajan, P. (2009). The relationship between ethics, common sense, and rationality. Management decision, 47(3), 481-490.

Nimalathasan, B., \& Valeriu, B. (2010). Association between critical, creative thinking and problem solving in accounting researchers: an overview. Young Economists Journal, 8(14), 7-12.

Palaniappan, A. K. (2014). Evaluating creative and innovative teaching. Journal of social science research, October, 25-35.

Pally, M. (2001). Skills Development in 'Sustained' Content-Based Curricula: Case Studies in Analytical/Critical Thinking and Academic Writing. Language and Education, 15(4), 279-305.

Paul, R. W. (1989). Critical Thinking in North America: A New Theory of Knowledge, Learning, and Literacy. Argumentation, 3(2), 197-235.

Paul, R., \& Elder, L. (2012). Critical Thinking: Tools for Taking Charge of Your Learning and Your Life, $3^{\text {rd }}$ Edition. USA: Pearson.

Phillip, C. (2009). 50 Puzzles for Logical Thinking. USA: Bibelot Limited.

Pinard, M. C., \& Allio, R. J. (2005). Innovations in the classroom, Improving the creativity of MBA students. Strategy \& Leadership, 33(1), 49-51.

Profetto-McGrath, J. (2003). Critical Thinking and Evidence-Based Practice. Journal of Professional Nursing, 21(6), 364-371.

Tabachnick, B., \& Fidell, L.S. (2013). Using Multivariate Statistics (Sixth Edition). Boston: Pearson Education, Inc.

Tan, O. (2006). Problem-based learning pedagogies: Psychological processes and enhancement of intelligences. APERA Conference, 28-30 November 2006, Hong Kong, 1-17.

Trach, J. S. (2012). Degree of collaboration for successful transition outcomes. Journal of Rehabilitation, 78, 39-48.

Renner, J.W. \& Philips, D.G. (1980). Piaget's developmental model: A basis for research in science education. School Science and Mathematics, 80, 193-198.

Rose, C. P., Wang, Y., Cui, Y., Arguello, J., \& Stegmann, K. (2008). Analyzing collaborative learning processes automatically: Exploiting the advances of computational linguistics in computer supported collaborative learning. International Journal of Computer Supported Collaborative Learning, 3, 237-271.

Saaty, T. L. (1994). How to Make a Decision: The Analytic Hierarchy Process. Interfaces, 24, 19-43.

Segars, A. H., \& Grover, V. (1993). Re-examining perceived ease of use and usefulness: A confirmatory factor analysis. MIS Quarterly, 17(4), 517-525.

Simpson, E., \& Courtneay, M. (2002). Critical thinking in nursing education: Literature review. International Journal of Nurse Practice, 8, 89-9.

Steiger, J. H. (2007). Understanding the limitations of global fit assessment in structural equation modeling. Personality and Individual Differences, 42, 893-898.

Wagner, T. (2018). Tony Wagner's Seven Survival Skills. Retrieved December 27, 2018, from http://www.tonywagner.com/7-survival-skills/.

Wegerif, R. (2002). Literature Review in Thinking Skills, Technology and Learning. FutureLab Series: Open University. UK: Futurelab.

Wolff, T. (2010). The Power of Collaborative Solutions (Six Principles and Effective Tools for Building Healthy Communities). USA: Jossey-Bass.

142 Journal of Management Policy and Practice Vol. 20(2) 2019 